competent guides and interpreters will be provided by "Voks ", the Soviet organisation for cultural relations with foreign countries. Full particulars can be obtained from the Society for Cultural Relations, 1 Montague Street, London, W.C.1.

\section{Royal Institute of Public Health}

THE annual Congress of the Royal Institute of Public Health will be held in Belfast on May 10-15, under the presidency of the Marquess of Londonderry. The Congress will be divided into the following Sections: I., State Medicine and Municipal Hygiene; II., Industrial Hygiene; III., Women and Children and the Public Health ; IV., Tuberculosis ; V., Pathology, Bacteriology, and Biochemistry. The inaugural meeting will be held in the Great Hall of Queen's University, at 11 A.M. on May 10, when the presidential address will be delivered. Several general excursions have been arranged, besides sectional visits to hospitals, sanatoria, etc., and certain institutions, centres, and works will be open for inspection. Further information can be obtained on application to the Secretary, Royal Institute of Public Health, 37 Russell Square, London, W.C.1.

\section{Anti-Malarial Measures}

Sir Malcolm Watson stated at a meeting held in January of the Industrial Anti-Malarial Advisory Committee of the Ross Institute for Tropical Diseases that while Paris green has a place in malaria control, it is not a substitute for oiling surface waters that breed mosquitoes, for the female can safely lay its eggs in water treated with Paris green, but is killed by water that has been oiled. The nature of the crude oil forming the basis of anti-malarial oiling mixtures has an important bearing on efficiency, and Dr. Ramsay, in association with the Burma Shell Group, has completed researches upon the oils best suited for such mixtures.

\section{Joint Archæological Expedition to Antioch}

Arrangements have been made, we learn from Science Service, Washington, D.C., between Princeton University, New Jersey, and the Musée National of France, the Baltimore Museum of Art, and the Worcester Art Museum, for a joint expedition of excavation at Antioch. A five-year programme of excavation has been arranged. Prof. George W. Elderkin, of Princeton, is leaving immediately for Antioch to initiate the work. It is expected that it will be possible to excavate this ancient city without any disturbance of existing buildings.

\section{Announcements}

$W_{E}$ much regret to announce the death, on March 26 , at the age of seventy-seven years, of the Right Hon. Sir Horace Plunkett, K.C.V.O., F.R.S., first vice-president of the Department of Agriculture and Technical Instruction for Ireland and a pioneer in the organisation and development of Irish agriculture.

AT the March meeting of the Council of the Institute of Actuaries, Mr. W. Palin Elderton was elected president to succeed Mr. H. M. Trouncer, whose term of office expires in June.
Mr. Aldous Huxuey will deliver the Huxley Memorial Lecture at the Imperial College of Science and Technology, South Kensington, London, S.W.7, on May 4, at 5.30 Р.м. The subject of the lecture will be "Huxley as a Literary Man".

Aт the annual business meeting of the Royal Philosophical Society of Glasgow, held on March 23, the following officers were elected: Vice-President, Dr. Henry L. G. Leask; Hon. Librarian, Dr. James Knight ; Hon. Treasurer, Sir John Mann ; Secretary, Mr. John A. Buyers; Members of Council, Mr. John P. Heslin, Miss M. A. Hannan Watson, and Mr. George B. Wishart.

LoRD WAKEFIELD has given a sum of $£ 25,000$, spread over seven years, as a contribution to the Imperial Institute. The Institute is financed by annual grants from the Treasury, the Dominions, India, and the Colonies, and was faced with the prospect of curtailment of its activities, owing to temporary reduction of some of its supporting grants. It is hoped that Lord Wakefield's gift will enable the Imperial Institute to tide over the period of difficulty.

A course of three public lectures on "The Rôle of Statistical Method in Industrial Standardisation" will be given by Dr. W. A. Shewhart at University College, Gower Street, London, W.C.1, on May 3, 5, and 6 , at 5.30 P.M. Dr. Shewhart is a member of the technical staff of the Bell Telephone Laboratories, New York, and in these lectures an attempt will be made to outline the present status of the applications of modern statistics. A syllabus of the lectures may be obtained on application to the Academic Registrar, University of London, South Kensington, London, S.W.7.

Applications are invited for the following appointments, on or before the dates mentioned :-A public librarian under the Colwyn Bay Urban District Council-The Clerk to the Urban District Council, Council Offices, Colwyn Bay (April 14). An assistant curator in the Royal Botanic Gardens, Kew, in charge of the Decorative Department-The Secretary, Ministry of Agriculture and Fisheries, 10 Whitehall Place, S.W.1 (April 15). A mathematical master at the Royal Naval College, Dartmouth-The Headmaster, Royal Naval College, Dartmouth (April 18). A professor of philosophy at Armstrong College-The Registrar, Armstrong College, Newcastle-upon-Tyne (April 20). An assistant in the Natural History Department of the University of Aberdeen-The Secretary, University, Aberdeen (April 20). A reader in chemical engineering at the Imperial College (Royal College of Science)-The Academic Registrar, University of London, South Kensington, S.W.7 (April 22). A professor of zoology at Armstrong College and director of the Dove Marine Laboratory-The Registrar, Armstrong College, Newcastle-upon-Tyne (April 23). A whole-time radiologist at the Johannesburg Hospital-The Superintendent, Johannesburg Hospital, Johannesburg, South Africa (May 25). A male laboratory assistant at the Government Experimental Station, Porton-The Commandant, Experimental Station, Porton, near Salisbury. 